\title{
Effect of Flavourings on Quality and Consumer Acceptability of Soy-Yoghurt
}

\author{
Oyeniyi A.O. ${ }^{1}$, Aworh O.C. ${ }^{2}$, \& Olaniyan J.O. ${ }^{1}$ \\ ${ }^{I}$ Department of Home \& Rural Economics Oyo State College of Agriculture, Igboora, Oyo State, Nigeria \\ ${ }^{2}$ Department of Food Technology, University of Ibadan, Ibadan, Oyo State, Nigeria
}

\begin{abstract}
Inspite of the characteristic objectionable painty odour, soybean is an attractive value added food grain because of its higher nutritive value. The effect of different flavourings on the quality and acceptability of soy-yoghurt were studied. The flavours were added at 5\% (W/V). Soy-yoghurt flavoured with synthesized vanilla, banana, strawberry, pineapple and natural ginger flavours, control without flavouring and commercial yoghurt were all compared for proximate, $\mathrm{pH}$, percentage lactic acid, specific gravity, soluble solids, percentage syneresis and microbial count. Sensory evaluation was also conducted in order to determine the acceptability of the samples. The protein content of plain soy-yoghurt was 3.33; commercial yoghurt was 3.74 while that of flavoured soy-yoghurt ranged from 3.47 and 3.69. The $\mathrm{pH}$ and \%lactic acid contents ranged from 4.2-5.0 and 0.70-1.31 respectively on the second day of storage while the values were 4.0-4.7 and 1.30-1.71 on the eighth day of storage at refrigeration temperature. The lactic acid values increased with decreasing $\mathrm{pH}$ values. The \%syneresis ranged from 41.30-54.09 and 42.65-56.21 for flavoured soy-yoghurt while it was 37.75 and 38.13 for plain soy-yoghurt on the second and eighth day of storage. The values increased with increasing storage days. Microbiological examination revealed that the samples were within the minimum acceptable standards. The sensory evaluation also showed that there was no significant difference $(P \leq 0.05)$ for taste, consistency and overall acceptability among all the samples. However, banana soy-yoghurt was the most preferred by the sensory panelists with respect to all quality attributes except consistency while ginger soyyoghurt was the least preferred with respect to all quality attributes except taste.
\end{abstract}

Key Words: Consumer acceptability, flavourings, objectionable painty odour, quality, soy-yoghurt.

\section{Introduction}

Yoghurt is pasteurized milk or low-fat milk coagulated to a custard-like consistency with a mixed pure lactic acid culture containing Lactobacillus bulgaricus and Streptococcus thermophilus[1]. It is most often flavoured with fruit preserves or other ingredients but is also consumed unflavoured (plain yoghurt). Yoghurts are usually eaten as such but can be used as ingredients in desert products and candy bars and as frozen softserve product. Yoghurt products have high viscosity and generally set in weak gel. To enhance gel formation and to increase the viscosity of the finished product, a high solid content is desirable. In most cases, concentrated milk or non-fat dry milk is added to increase the solid content [2].

Yoghurt, a fermented milk product obtained by souring of milk using a mixed pure lactic acid culture can be manufactured from liquid cow milk, powdered milk and vegetable milk (soymilk) as base materials [3]. Milk is a unique substance in that it is consumed as fluid milk with minimal processing and it is the raw material used to manufacture a wide variety of products. Milk also has unique nutritional properties that make it an especially important food, particularly for the young ones. Milk is the normal secretion of the mammary glands of all mammals. Its purpose is to nourish the young of the species. The nutritional needs of species vary and so it is not surprising that the milk from different mammals differs in composition [1]. Milk provides the sole source of nourishment during the period directly after birth for a newborn mammal of the particular species of animal. It has a high nutritional value and thus, cow's milk is not only a complete food for babies and young children but also an excellent and valuable food for adults [4].

Soymilk is milk produced from soybeans. Soybeans are generally considered to be a source of complete protein. A complete protein is one that contains significant amount of all the essential amino acids that must be provided to the human body because of the body's inability to synthesize them. For this reason, soy is a good source of protein, amongst many others, for many vegetarians and vegans or for people who cannot afford milk and meat, since it is the least expensive source of dietary protein. The gold standard for measuring protein quality, since 1990, is the Protein Digestibility Corrected Amino Acid Score (PDCAAS) and by this criterion soy protein is the nutritional equivalent of meat and eggs for human growth and health. Soybean protein isolate has a biological value of 74, whole soybeans 96, soybean milk 91, and eggs 97 [5]. The increasing concern about fat and cholesterol content of animal milk is another factor promoting the selection of vegetable substitute for animal milk. Unsaturated fatty acid in the diet is recommended to reduce the incidence of cardiovascular disease [6]. Consumption of vegetable milk may also be beneficial in cases of lactose intolerance. 
Efforts have been devoted to exploiting soybean and soybean products for the manufacture of palatable food products [7]. Products obtainable from soymilk include soy yoghurt, soy cheese, soy ice cream and the likes. Enrichment of cereal-based traditional weaning food by complementing with soybean tempeh has been reported [8]. These attributes have been reported to make soybean potentially an excellent food crop for the protein deficient countries of the world [9] [10].

One of the major limiting factors that are hindering the use of soybeans in foods is the flavour, which is objectionable. Flavours are very important in food appreciation [11]. It is a complex of sensations derived from food, including the sensations of taste and smell [12]. However, flavour play a very important role in the judgment of the consumer and in this respect, the off-flavor inherent in unrefined soy-products places them at a distinct disadvantage [2]. Volatile components or compounds that arise from three main sources, including the beans themselves, processing and deterioration during storage, are responsible for highly characteristic odour associated with soybean and its various products, which in many case are undesirable and even offensive. As a result, there is need to suppress these odours by subjecting the products to different flavours. The use of different fruit flavourings in soy-yoghurt has been attempted increasingly.

\subsection{Materials}

\section{Materials And Methods}

The Soybean seeds were obtained from Bodija market in Ibadan, Oyo State. Good quality and mouldfree seeds were selected. Electric cooker, steam/water bath, hammer mill, plastic bowls, muslin cloth, thermometer, blender, freezer, beaker, electric oven, conical flasks, stirrer, chemical and media were gotten from the Food Processing Laboratory, University of Ibadan, Oyo State. Also, materials like stabilizer (Carboxyl Methyl Cellulose, CMC), sucrose (granulated sugar), glucose, synthetic flavours (banana, pineapple, strawberry, vanilla) and ginger powder were purchased from a retail shop in Ibadan, while freeze-dried starter culture was purchased from a supermarket in Ojota, Lagos State.

\subsection{Methods}

\subsubsection{Production of Soybean Milk}

$1000 \mathrm{~g}$ of soybean seeds were cleaned and soaked overnight in cold $0.5 \% \mathrm{NaHCO}_{3}$ solution with plenty of cold water $\left(5000 \mathrm{~cm}^{3}\right)$. The soaked bean was then blanched in $0.5 \% \mathrm{NaHCO}_{3}$ solution for about 10 minutes, washed in cold water and milled into paste while water was added in ratio 1:4 to give $12 \%$ total solid. The slurry was strained and the recovered milk was cooked for about $20-30$ minutes at $82^{\circ} \mathrm{C}$ while stirring continuously with a wooden stirrer to prevent from burning. The milk was homogenized using a blender and cooled to $45^{\circ} \mathrm{C}$ [13] [14] [15]. Fig 1 shows the flow chart for soymilk production.

\subsubsection{Production of Yoghurt} shown in Fig 2 .

The recovered milk (soymilk) was used to prepare yoghurt. Various step involved in the preparation is 


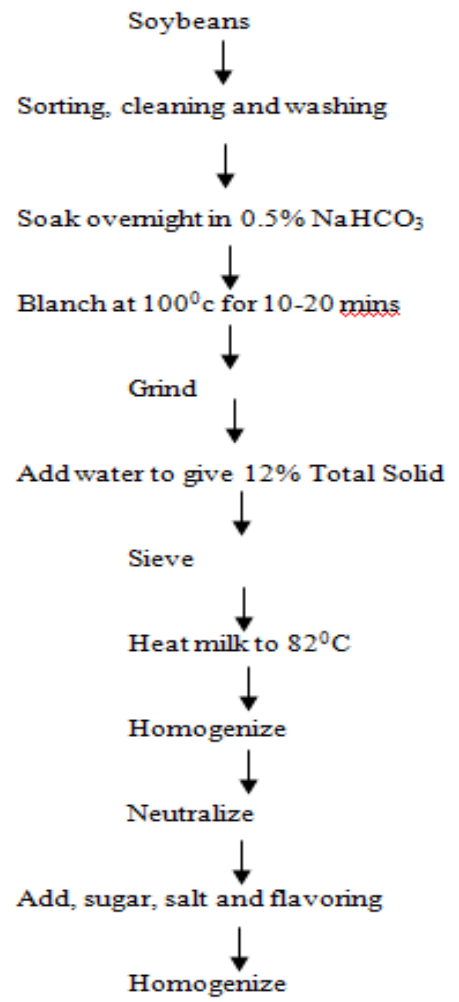

Source: [13] [14].

Figure 1: Process Flow Chart for Soymilk

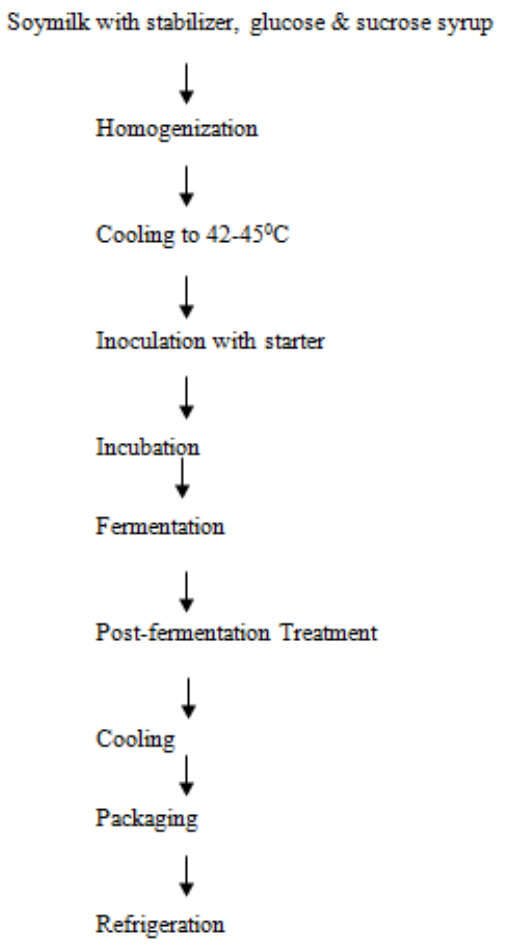

Figure 2: Process Flow Chart for Yoghurt Production Source: [16] [17].

\subsection{Homogenization}

Immediately after boiling, the milk was homogenized using blender while $0.3 \%$ stabilizer, $1 \%$ glucose and 5\% sugar (syrup) were added and mixed together. The order of addition of various ingredients was 
determined by their temperature and solubility. The mix was then cooled rapidly in cold-water bath to $42-45^{\circ} \mathrm{C}$ after having obtained a homogenous mix [17].

\subsection{Fermentation Process}

Yoghurt is fermented at $40-45^{\circ} \mathrm{C}$, the optimum growth condition for the mixed culture (L. bulgaricus and $S$. thermophilus). $5 \mathrm{~g}$ of starter culture was added to 1 litre of milk, mixed with a glass rod for even distribution and filled into plastic containers. The containers were covered to minimize the possibility of contamination while the milk was incubated at $42^{\circ} \mathrm{C}$ for 6 hours undisturbed until the desired custard consistency was reached [16] [17].

\subsection{Post-fermentation Treatments}

The fresh-made yoghurt is ready for consumption when it is set. However, $5 \%$ sweetener and different flavour was added at $5 \% \mathrm{~W} / \mathrm{V}$ to each of the milk samples.

\subsection{Cooling and Packaging}

Yoghurt production is a biological process and cooling is one of the popular methods used to control the metabolic activity of the starter culture and its enzymes. The coagulum was cooled directly after fermentation while the acidity reaches about $\mathrm{pH} 4.6$ and this was done by refrigeration [18]. The yoghurt was then packaged in polyethylene bags and plastic containers.

\subsection{Analyses}

The quality parameters carried out include the physicochemical, proximate and microbiological analyses. The percentage yield for the soymilk was done using the methods described by [19] and [20], the total solids, total titratable acidity and specific gravity measurements were determined by [21] technique while $\mathrm{pH}$ determination was done using $\mathrm{pH}$ metre.

The proximate analysis determined involved the moisture content, the fat content, the crude protein content, the ash content, the total solid content and the carbohydrate content. The carbohydrate content was determined by difference while all others were done with the [21] methods.

For the microbiological analysis, the sample media was prepared first before carrying out the analyses. One millilitres of sample mixture was aseptically pipetted into a test tube containing $9 \mathrm{ml}$ sterile distilled water and serial dilutions was made to make $10^{-5}$ dilution. Growth media was prepared according to specifications on the containers. Total viable counts, fungal counts, and coliform counts were determined by the methods described by [22] [23] respectively.

\subsection{Sensory Evaluation}

Sensory evaluation was carried out on the soy-yoghurt samples containing different flavours. An organoleptic study was carried out to evaluate the level of acceptability of the samples. Ten-member panels of judges consisting of people that are conversant with yoghurt in Ibadan city were constituted. The panelists were asked to rate the samples for taste, appearance/colour, odour/aroma, consistency, and overall acceptability using a 7-point hedonic scale where 1 to 7 represent dislike extremely (1) to like extremely (7) [24].The responses generated were analysed using one-way Analysis of Variance (ANOVA) in a Completely Randomized Design.

\section{Results and Discussion}

The proximate composition of the soymilk and soy-yoghurt produced are presented in Table 1 . The analyses were carried out on soymilk and each soy-yoghurt samples with different flavourings. The protein content reported in freshly prepared soymilk is comparable to $3.58 \%$ reported by [25] and a little lower than that reported by USDA Nutrient Database for Standard Reference (2004). There are no appreciable difference between the protein content in the milk and yoghurt samples, this may be due to errors in the analyses and or processing. [7] recommended that the total solid of soymilk used for the production of soy-yoghurt should range between 9 to $12 \%$, therefore the total solid content is comparable. The total solid content for each yoghurt samples were between 12.21 and 14.09 and are higher than that obtained in soymilk. The percentage yield of the milk used was $65.7 \%$ while the ratio of slurry to water was 1:4. This is a little higher than the result obtained by [27] which could be as a result of water to slurry ratio. All other proximate compositions are within the range reported by [7].

[7] reported the lactic acid of about $0.9-1.08$ in soy-yoghurt. The value reported in this study is comparable and considered satisfactory. The $\mathrm{pH}$ value reported for cow milk ranged between 6.6 and 6.7 according to [28], whereas the $\mathrm{pH}$ value of the freshly prepared soymilk was 7.0 while that of soy-yoghurt ranged between 4.2 to 5.0. Table 2 shows the $\mathrm{pH}$ value of freshly prepared soymilk and $\mathrm{pH}$ value and lactic acid content of soy-yoghurt samples on the $2^{\text {nd }}$ and $8^{\text {th }}$ days of storage. The lactic acid contents increased with 
decreasing $\mathrm{pH}$ values at refrigeration temperature. The change in $\mathrm{pH}$ and lactic acid content indicated that the activity of the starter culture was not completely arrested though markedly decreased.

The specific gravity and soluble solid content of the soy-yoghurt samples are shown in Table 3. [29] reported that the specific gravity of pure milk should range between 0.9396 and 1.5125 . If it is a little below 0.9396 it is still regarded as pure but if it is higher than 1.5125 it is impure, therefore the specific gravity of each samples are satisfactory because it is comparable to that reported by [29]. There were irregularities in values of the soluble solids reported for each samples with plain and strawberry soy-yoghurts having the lowest soluble solid content in this order. The soluble solid content of these samples are generally lower than that reported by [7].

The percentage syneresis ranged between 37.75 to $54.09 \%$ on the $2^{\text {nd }}$ day and 38.13 to $56.21 \%$ on the $8^{\text {th }}$ day of production (Table 4). [7] reported the range of 40.9 to $47.0 \%$ on the $1^{\text {st }}$ day and 42.6 to $52.7 \%$ on the $8^{\text {th }}$ day of production. [30] reported an average of $52.6 \%$ syneresis in soy-yoghurt fortified with $1.104 \%$ calcium sulphate. [31] reported an average of 31.5\% in Mexican plain yoghurt. However, with the addition of $0.3 \%$ gelatin and $0.104 \%$ calcium sulphate [32], a range from 42.06 to $46.3 \%$ syneresis was obtained for flavoured soy-yoghurt. In this study, higher percentage syneresis was reported for vanilla soy-yoghurt in comparison with other samples.

The microbial populations of the soy-yoghurt samples are shown in Table 5. The microbiological evaluation was done to examine the finished product on the survival of starter organisms as well as the presence of undesirable spoilage and pathogenic organisms. The total viable count was between $210 \times 10^{6}$ and $380 \times 10^{6}$ $\mathrm{CFU} / \mathrm{ml}$ while fungal count was between 1.1 and $1.6 \mathrm{CFU} / \mathrm{ml}$ and there was no count for coliform. The fungal count reported could be due to the microorganisms present in the inoculums as a result of careless handling during production and analysis, but it is more reduced than the amount found in the commercial yoghurt that was used as the control. [33] reported that the total viable count of yoghurt should be greater than $200 \times 10^{6}$, and the yeast count less than $10 / \mathrm{ml}$ while the coliform $/ \mathrm{ml}$ count should be less than 1 . The absence of coliform signifies that all the samples were free from faecal contamination therefore the microbial status of the soyyoghurt samples conforms to the accepted standard.

The mean scores for quality attributes of the soy-yoghurt samples are shown in Table 6 . The result shows that there was no significant difference for taste, consistency and overall acceptability among the treatments. Banana soy-yoghurt was the most preferred by the sensory panelists with respects to all quality attributes except consistency, the consistency of plain soy-yoghurt was the most preferred. Ginger soy-yoghurt was the least preferred by the panelists with respect to all quality attributes except taste.

TABLE 1: The proximate composition of freshly prepared soymilk and soy-yoghurt samples

\begin{tabular}{lllllll}
\hline & & \multicolumn{7}{l}{$\%$} & & \\
\cline { 2 - 6 } Samples & Protein & Total solids & Moisture & Fat & Ash & Carbohydrate \\
\hline Freshly prepared soymilk & $3.58 \pm 0.11$ & $10.50 \pm 0.21$ & $89.74 \pm 1.05$ & $2.80 \pm 0.07$ & $0.69 \pm 0.01$ & $3.19 \pm 0.01$ \\
Vanilla soy-yoghurt & $3.47 \pm 0.07$ & $13.50 \pm 0.03$ & $86.50 \pm 0.99$ & $3.30 \pm 0.14$ & $0.74 \pm 0.03$ & $5.99 \pm 0.01$ \\
Strawberry soy-yoghurt & $3.59 \pm 0.11$ & $14.09 \pm 0.14$ & $85.91 \pm 0.01$ & $3.10 \pm 0.07$ & $0.79 \pm 0.01$ & $6.61 \pm 0.01$ \\
Pineapple soy-yoghurt & $3.62 \pm 0.10$ & $14.08 \pm 0.04$ & $85.92 \pm 0.26$ & $3.00 \pm 0.03$ & $0.71 \pm 0.04$ & $6.75 \pm 0.03$ \\
Banana soy-yoghurt & $3.54 \pm 0.01$ & $13.91 \pm 0.06$ & $86.09 \pm 0.03$ & $3.40 \pm 0.07$ & $0.76 \pm 0.01$ & $6.21 \pm 0.01$ \\
Ginger soy-yoghurt & $3.69 \pm 0.01$ & $12.95 \pm 0.06$ & $87.05 \pm 0.64$ & $3.50 \pm 0.07$ & $0.83 \pm 0.01$ & $4.93 \pm 0.03$ \\
Plain soy-yoghurt & $3.33 \pm 0.24$ & $12.55 \pm 0.49$ & $87.45 \pm 0.07$ & $3.60 \pm 0.14$ & $0.62 \pm 0.03$ & $5.00 \pm 0.06$ \\
Commercial yoghurt & $3.74 \pm 0.03$ & $12.21 \pm 0.13$ & $87.79 \pm 0.10$ & $3.20 \pm 0.04$ & $0.69 \pm 0.01$ & $4.58 \pm 0.01$ \\
\hline
\end{tabular}

Results are mean \pm SD of samples in duplicate.

TABLE 2: The $\mathrm{pH}$ value and lactic acid content of freshly prepared soymilk and soy-yoghurt samples on the $2^{\text {nd }}$ and $8^{\text {th }}$ day

\begin{tabular}{|c|c|c|c|c|}
\hline Samples & $\mathrm{pH}$ & $\frac{2^{\text {nd }} \text { day }}{\text { Lactic acid }(\%)}$ & $\mathrm{pH}$ & $\frac{8^{\text {th }} \text { day }}{\text { Lactic acid }(\%)}$ \\
\hline \multicolumn{5}{|c|}{ Freshly prepared soymilk 7.0} \\
\hline Vanilla soy-yoghurt & 4.3 & 1.06 & 4.0 & 1.70 \\
\hline Strawberry soy-yoghurt & 5.0 & 0.70 & 4.7 & 1.30 \\
\hline Pineapple soy-yoghurt & 4.7 & 0.74 & 4.5 & 1.44 \\
\hline Banana soy-yoghurt & 4.2 & 0.82 & 4.0 & 1.42 \\
\hline Ginger soy-yoghurt & 4.4 & 0.89 & 4.0 & 1.51 \\
\hline Plain soy-yoghurt & 4.3 & 0.86 & 4.0 & 1.46 \\
\hline Commercial yoghurt & 4.5 & 1.13 & 4.0 & 1.71 \\
\hline
\end{tabular}

Mean of two determinations in each of two replicate samples 
Table 3: The specific gravity and soluble solid content of soy-yoghurt samples

\begin{tabular}{llc}
\hline Samples & Specific gravity & soluble solid content (\%) \\
\hline Vanilla soy-yoghurt & 0.8910 & 19.24 \\
Strawberry soy-yoghurt & 0.8462 & 13.37 \\
Pineapple soy-yoghurt & 0.8865 & 15.29 \\
Banana soy-yoghurt & 0.7867 & 15.23 \\
Ginger soy-yoghurt & 0.8628 & 15.23 \\
Plain soy-yoghurt & 0.9000 & 11.38 \\
Commercial yoghurt & 0.9396 & 15.62 \\
\hline
\end{tabular}

TABLE 4: The percentage syneresis of soy-yoghurt samples on $2^{\text {nd }}$ and $8^{\text {th }}$ day

\begin{tabular}{lcc}
\hline Samples & $2^{\text {nd }}$ day & $(\%)$ \\
\hline Vanilla soy-yoghurt & 54.09 & $8^{\text {th }}$ day \\
Strawberry soy-yoghurt & 43.88 & 56.21 \\
Pineapple soy-yoghurt & 41.30 & 44.96 \\
Banana soy-yoghurt & 43.80 & 42.65 \\
Ginger soy-yoghurt & 47.94 & 45.28 \\
Plain soy-yoghurt & 37.75 & 48.25 \\
Commercial yoghurt & 40.08 & 38.13 \\
\hline
\end{tabular}

TABLE 5: The Microbiological evaluation of soy-yoghurt samples

\begin{tabular}{|c|c|c|c|}
\hline Samples & Total count $\times 10^{6}$ & $\begin{array}{l}(\mathrm{CFU} / \mathrm{ml}) \\
\text { fungal count } \times 10^{4}\end{array}$ & Coliform count $\times 10^{3}$ \\
\hline Vanilla soy-yoghurt & 240 & 1.3 & - \\
\hline Strawberry soy-yoghurt & 210 & 1.1 & - \\
\hline Pineapple soy-yoghurt & 270 & 1.7 & - \\
\hline Banana soy-yoghurt & 290 & 1.4 & - \\
\hline Ginger soy-yoghurt & 290 & 1.5 & - \\
\hline Plain soy-yoghurt & 380 & 1.6 & - \\
\hline Commercial yoghurt & 310 & 2.6 & - \\
\hline
\end{tabular}

: Not found

TABLE 6: Mean ranks for quality attributes of soy-yoghurt samples

\begin{tabular}{lllllll}
\hline & \multicolumn{5}{c}{ Flavors } \\
\cline { 2 - 7 } Attributes & \multicolumn{7}{c}{ Banana Strawberry } & Pineapple & Vanilla & Ginger & Plain \\
\hline Taste & $6.3^{\mathrm{a}}$ & $5.8^{\mathrm{b}}$ & $5.7^{\mathrm{b}}$ & $5.7^{\mathrm{b}}$ & $5.8^{\mathrm{b}}$ & $6.2^{\mathrm{a}}$ \\
Color & $5.9^{\mathrm{ab}}$ & $5.6^{\mathrm{b}}$ & $5.9^{\mathrm{ab}}$ & $5.2^{\mathrm{bc}}$ & $4.8^{\mathrm{c}}$ & $5.8^{\mathrm{b}}$ \\
Aroma & $6.1^{\mathrm{a}}$ & $5.8^{\mathrm{b}}$ & $5.8^{\mathrm{b}}$ & $5.7^{\mathrm{b}}$ & $5.3^{\mathrm{bc}}$ & $5.7^{\mathrm{b}}$ \\
Consistency & $5.5^{\mathrm{ab}}$ & $5.5^{\mathrm{ab}}$ & $5.5^{\mathrm{ab}}$ & $5.2^{\mathrm{bc}}$ & $5.2^{\mathrm{bc}}$ & $5.7^{\mathrm{ab}}$ \\
Overall Acceptability & $6.1^{\mathrm{a}}$ & $6.1^{\mathrm{a}}$ & $5.8^{\mathrm{b}}$ & $5.9^{\mathrm{b}}$ & $5.8^{\mathrm{b}}$ & $6.1^{\mathrm{a}}$ \\
\hline
\end{tabular}

Values in the same row with the same superscripts are not significantly different $(\mathrm{p}<0.05)$

\section{Conclusions}

Increasingly, low milk production in West Africa to meet the present population demand, high cost of milk, the protein demand in developing countries of the world, incidence of cardiovascular disease, lactose intolerance and other contributing factors has led to efforts in finding alternative sources of protein in legume seeds and production of "imitation milk". Production of yoghurt and other dairy products from soybeans should be of considerable economic interest/importance.

It was found in this study that there was no appreciable difference between the chemical composition of the soy-yoghurt samples and the commercial yoghurt made with cow milk. Microbiologically, the samples were free from faecal contamination. Also the samples were not significantly different from each other in terms of flavouring but banana soy-yoghurt was the most preferred while ginger soy-yoghurt was the least preferred. Flavourings enhance the acceptability of soy-yoghurt, and if this is being done for all other soy-products, they will be more acceptable by the public and the overall nutritional status of the populace in the developing countries will be improved. 


\section{References}

[1] Potter, N.N., and Hotchkiss, J.H. 2006. Food science $5^{\text {th }}$ Ed. (New York, CBS Publishers), Pp.24.

[2] Iwe, M.O. 2003. The science and technology of soybean: chemistry, nutrition, processing, and utilization (Enugu, Nigeria, Rejoint Communications Services Ltd). Pp 1-286.

[3] FAO 1999. Technology of Production of Edible Flours and Protein Products from Soybeans. FAO Agricultural services Bulletin No.97.

[4] Potter, N.N. 1987. Food Science. $3^{\text {rd }}$ Ed. (New York: Cornell University Publisher).

[5] FAO. 1991. Protein Quality - Report of Joint FAO'/WHO Expert Consultation, Food and Agriculture Organization, Rome, FAO Food and Nutrition Paper 51.

[6] Lee, S.Y., Marr, C.V. and Seo, A. 1990.Comparison of Milk-based and Soymilk-based Yoghurt. J. Food Sci., 55: 532-536.

[7] Osundahunsi, O.F., Amosu, D. and Ifesan, B.O.T. 2007.Quality Evaluation and Accpetability of Soy-yoghurt with Different Colours and Fruit Flavours. American Journal of Food Technology, 2(4): 273-280.

[8] Osundahunsi, O.F. and Aworh, O.C. 2003. Nutritional Evaluation, with Emphasis on Protein Quality, of Maize-based Complementary Foods Enriched with Soybean and Cowpea Tempe. Int. J. Food Sci. Technol., 38: 809-813.

[9] Parman, G.K. 1974.Agency for International Development's Program for Development and Utilization of Soybeans in the Developing World. J. Am. Oil Chemists' Society, Vol. 51. Pp. 150 A-151A.

[10] Liu, K. 2000. Expanding Soybean Food Utilization.J. Food Technol. 54 (7), 46-47.

[11] Visser, A. and Thomas. A. 1987. Review: Soya Protein Products, their Processing, Functionality, and Application Aspects. Food Reviews Int'1. 31 (182), p1-32.

[12] Ihekoronye, A.I. and Ngoddy, P.O. 1985. Integrated Food Science and Technology for the Tropics (London and Basingstoke: Macmillian Publishers).

[13] Nelson, A.I., Steinberg, M.P. and Wei, L.S. 1975. Illinois Process for Preparation of Soymilk.J. Food Sci., 41:57-61.

[14] Carison, J. 1976. New Interest in Soymilk. Soybean Digest, 36 (11): 23-25. Citrulisvulgaris. Pp. 2-11.

[15] Mayhew, S. and Penny, A. Macmillan tropical and sub-tropical foods(London and Basingstoke, Macmillan Publishers, 1998).

[16] Driessen, F.M., Ubbels, J., and Stadhouders, J. Continuous manufacture of yoghurt. In: Optimal conditions and kinetics of the prefermentationprocess. (Biotech.Boieng., 19:821, 1977).

[17] Tamime, A.Y. and Deeth H.C. 1980: Yoghurt technology and Biochemistry. J. Food Protection, 43:939.

[18] Tamime, A.Y; and Robinson, K.K. 1989. Yoghurt, Science and Technology(Reprint.First Ed. Pergamon Press, New York).

[19] Olukoya, D.K., Abaelu, A.M., Daranijo, R.B., Iwuye, M. K., and Akinmisi, E.O. 1992. Preparation of Melon Milk and Yoghurt-like Product from Melon (Egusi), Citrulis vulgaris.Pp. 2-11.

[20] Nwokolo, E. 1996. Peanut (Arachis hypogeal): Legumes and Oil Seeds in Nutrition(E. Nwokolo and J. Small Chapman and Hall Publishers).Pp. 49.

[21] AOAC 1985. Official Method of Analysis, Association of Official Analytical Chemist, Washington DC.

[22] Adegoke, G.O. Understanding Food Microbiology(Shalom Press, Ibadan, Nigeria, 2000) 129-191.

[23] Mundit, J.O. 1975. Unidentified Streptococci from International Journal System J. ofBacteriology, pp. 25, $281,285$.

[24] Gaffney, J.J. 1976. Quality Detection in Foods (American Society of Engineering, Michigan).

[25] STS, 1987. Soymilk in Brief. A Case that Makes Sense: Soya Technology Systems Ltd., Singapore.

[26] USDA 2004.United States Department of Agriculture, Nutrient database for standard reference,sAgricultural Statistics.

[27] Onuorah, C. E., Adejare, A. O. and Uhiara, N. S. 2007.Comparative physico- chemical evaluation of soymilk and soya cake producedby three different methods. Nigerian Food Journal,25(2): 32.

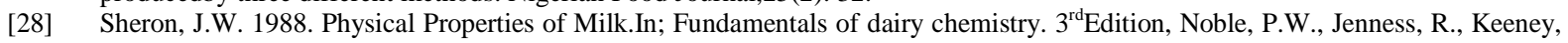
M. and Marth, E.H. (Eds), AVI Pubis Van No Strand Reinhold, New York.

[29] Davis, J.G. Dairy Chemistry $5^{\text {th }}$ Edition, (Oxford Press, London, 1993).

[30] Shirai, K., Gutiefrez-Duran, M., Marshall, Y.M.E., Revah-Moiseev, S. and Garcia-Garibay, N. 1992. Production of a Yoghurt-like Plant Product Foodstuff and Whey: Sensory Evaluation and Physical Attributes. J. Sci. Food Agric., 59: 205, pp. 102-104.

[31] Montano-Ortego, M., Aguilera-Valencia, G., Sanchez-Banuetos, J.M. and Garcia- Garibay M. 1991. AnalisisMicrobiologico, de ComposicionyCaracteristicasFisicoquimicas de Yogures Commercial y suRepercucion en suvida de Anaquel.IVCongresoPanamericano de la leche.GoudaLajacaJal, Mexico.

[32] Palotielo, M. M., Peddy, K.Y. and Da-Silva, R.S.F. 1987. Calcium Sulfate as Organoleptic Coadjuvant in the Formulation of Soyyoghurt. Labensmited - WissenSchaftnd-Technologie, 20: 155-157.

[33] Tamime, A.Y. and Robinson, R.K. Yoghurt science and technology (Wood head Publishing Ltd, Abington Hall, Cambridge England, 2004) 